\title{
Dampak Kebijakan Tarif dan Non-tarif Negara-Negara Importir atas Ekspor Tuna Olahan Indonesia
}

\section{(Impact of Tariff and Non-tariff Policies of Importing Countries on Indonesian Processed Tuna Exports)}

\author{
Maharani Tristi ${ }^{1 *}$, Harianto $^{2}$, Amzul Rifin ${ }^{2}$ \\ (Diterima Februari 2021/Disetujui Juli 2021)
}

\begin{abstract}
ABSTRAK
Penelitian ini bertujuan menganalisis dampak penerapan kebijakan tarif dan non-tarif negara-negara importir atas kinerja ekspor tuna olahan Indonesia. Dampak kebijakan dianalisis berdasarkan ekspor menggunakan crosssectional gravity model. Variabel yang digunakan antara lain produk domestik bruto (GDP) per kapita negara importir, populasi, jarak ekonomi, harga ekspor, nilai tukar riil, kebijakan tarif, dan kebijakan non-tarif berupa sanitary and phytosanitary (SPS) dan technical barriers to trade (TBT). Hasil estimasi menunjukkan bahwa variabel GDP per kapita negara importir, populasi, nilai tukar, harga ekspor, dan SPS berpengaruh positif dan nyata pada perdagangan komoditas tuna olahan Indonesia. Jarak ekonomi dan kebijakan TBT berpengaruh negatif dan nyata pada besarnya volume ekspor. Penerapan kebijakan tarif juga berpengaruh negatif pada besarnya volume ekspor komoditas ini tetapi tidak nyata.
\end{abstract}

Kata kunci: cross sectional gravity, kinerja ekspor, non-tarif, tarif

\section{ABTRACT}

This study aims to analyze the impact of the tariff and non-tariff policies implementation of the importing countries on the export performance of Indonesian processed tuna. A cross-sectional gravity model analysis was conducted to find out the impact of these policies on exports. The variables used include GDP per capita of the importing countries, population, economic distance, export prices, actual exchange rates, tariff policies, and non-tariff policies in the form of sanitary and phytosanitary (SPS) and technical barriers to trade (TBT). The estimation shows that the variables of GDP per capita of the importing countries, population, exchange rates, export prices, and SPS give a positive and significant effect on the trade of Indonesian processed tuna commodities. On the other hand, economic distance and TBT policy give a negative and significant impact on the volume of this particular commodity. Meanwhile, the tariff policy implementation also give a negative effect on the export volume, but it is not significant.

Keywords: cross sectional gravity, export performance, non-tariffs, tariffs

\section{PENDAHULUAN}

Perdagangan internasional di era globalisasi ini tidak hanya dihadapkan pada adanya kebijakan tarif, tetapi juga munculnya kebijakan non-tarif yang semakin banyak diterapkan. Menurut UNCTAD (2010), kebijakan non-tariff measure (NTM) adalah kebijakan selain tarif, yang berpotensi berdampak ekonomi pada perdagangan barang internasional, mengubah kuantitas yang diperdagangkan, atau harga, atau keduanya. Sejauh ini jumlah tindakan NTM terbanyak pada jenis sanitary and phytosanitary (SPS) dan technical barriers to trade (TBT) (TRAINS, 2019). Tingginya penerapan kebijakan SPS dan TBT ini dipengaruhi oleh meningkatnya perhatian konsumen

${ }^{1}$ Sekolah Pascasarjana, Program Studi Agribisnis, Fakultas Ekonomi dan Manajemen, Institut Pertanian Bogor, Kampus IPB Darmaga, Bogor 16680

2 Departemen Agribisnis, Fakultas Ekonomi dan Manajemen, Institut Pertanian Bogor, Kampus IPB Darmaga, Bogor 16680

* Penulis Korespondensi: Email: maharani.tristi@gmail.com dunia tentang isu-isu kesehatan yang menghendaki produk yang berkualitas dan aman, seiring dengan peningkatan pendapatan. Kebijakan tarif jenis SPS dan TBT semakin banyak diterapkan pada produk pertanian.

Tingginya penerapan kebijakan SPS dan TBT pada produk pertanian seperti sayuran, hewan, hingga makanan olahan adalah karena kelompok produk tersebut dapat berdampak langsung maupun tidak langsung pada kesehatan manusia. Di lain pihak, penerapan kebijakan non-tarif ini mengkhawatirkan negara-negara eksportir. Meningkatnya penerapan kebijakan non-tarif yang diterapkan oleh negara importir menimbulkan keresahan tersendiri bagi negara-negara eksportir khususnya negara berkembang. Penerapan kebijakan non-tarif ini dapat sangat menghambat perdagangan internasional dan dapat mencegah akses pasar khususnya bagi negara berkembang, salah satunya Indonesia.

Sebagai negara yang menganut sistem perekonomian terbuka, Indonesia mengandalkan kegiatan perdagangan internasional sebagai penggerak dalam 
pertumbuhan ekonomi. Kemendag (2011) mencatat bahwa sekitar $30 \%$ produk domestik bruto (PDB) Indonesia berasal dari ekspor. Ekspor produk perikanan merupakan komoditas andalan Indonesia untuk meningkatkan PDB. Sektor perikanan memiliki kontribusi terbesar kedua pada PDB Indonesia pada kelompok pertanian setelah subsektor tanaman perkebunan. Sumbangan PDB subsektor perikanan pada lima tahun terakhir meningkat setiap tahun dengan kenaikan rata-rata 4,80\% (KKP, 2018).

Tingginya PDB subsektor perikanan antara lain didukung oleh tingginya volume produksi perikanan Indonesia. Kondisi wilayah perairan Indonesia yang luas sangat mendukung produksi perikanan, baik perikanan tangkap maupun perikanan budi daya. Berdasarkan data FAO (2019), Indonesia merupakan negara produsen perikanan tangkap terbesar kedua di dunia setelah China, sedangkan untuk perikanan budi daya menempati urutan ketiga terbesar setelah China dan India. Walaupun dengan potensi sumber daya perikanan yang tinggi, hal tersebut belum dapat menjadikan Indonesia sebagai negara pengekspor terbesar perikanan. Indonesia harus menghadapi beberapa penerapan kebijakan non-tarif dari negara importir, terbukti dengan terjadinya beberapa kasus penolakan produk perikanan Indonesia. Irawati et al. (2018) menyatakan bahwa komoditas perikanan yang terbanyak ditolak di Uni Eropa adalah komoditas ikan tuna. Tercatat 27 kasus penolakan produk tersebut pada tahun 2011-2017, lebih tinggi dibandingkan dengan komoditas udang (10 kasus) dan kepiting (3 kasus).

Diterapkannya kebijakan non-tarif tersebut pada negara tujuan ekspor mengharuskan Indonesia lebih memperhatikan persyaratan yang telah ditentukan. Mutu ekspor produk harus diperbaiki dalam menghadapi persaingan di pasar global saat ini. Komoditas ikan tuna dalam berbagai bentuk, yaitu dalam bentuk segar, beku, filet, dan olahan, menempati posisi kedua terbesar dalam menyumbang nilai ekspor sektor perikanan Indonesia. Ikan tuna olahan memiliki nilai ekspor lebih tinggi dibandingkan ikan tuna bentuk lainnya. Pada tahun 2018 volume ekspor tuna olahan mencapai 82.234 ton dengan nilai ekspor USD 387.289.000 (Gambar 1). Hal ini merupakan dasar pemikiran untuk menganalisis dampak kebijakan tarif dan non-tarif negara-negara importir pada kinerja ekspor tuna olahan Indonesia.

\section{METODE PENELITIAN}

\section{Jenis dan Sumber Data}

Penelitian ini menggunakan data sekunder dari berbagai lembaga perdagangan dunia seperti World Bank, WTO, UNCTAD, UN Comtrade, ITC, dan CEPII. Komoditas ikan tuna yang menjadi objek penelitian adalah tuna dalam bentuk olahan (HS 160414). Jenis data yang digunakan untuk menganalisis dampak kebijakan tarif dan non-tarif pada kinerja ekspor tuna olahan adalah data cross section. Jumlah observasi data cross section sebanyak 40 negara yang merupakan negara importir tuna olahan Indonesia pada tahun 2018. Perincian jenis dan sumber data disajikan pada Tabel 1.

\section{Metode Analisis Data}

Penerapan kebijakan tarif dan non-tarif pada tuna olahan Indonesia dianalisis secara deskriptif kuantitatif. Analisis tersebut digunakan untuk memaparkan gambaran umum mengenai kebijakan perdagangan berupa tarif dan non-tarif yang diberlakukan oleh negara-negara importir pada komoditas tuna olahan Indonesia. Kemudian, untuk menelusur dampak kebijakan tarif dan non-tarif tersebut pada kinerja ekspor, dianalisis hubungan antara beberapa variabel seperti GDP, populasi, jarak ekonomi, nilai tukar, harga ekspor, kebijakan tarif dan non-tarif atas volume ekspor tuna olahan Indonesia. Analisis tersebut menggunakan model cross-sectional gravity. Variabel kebijakan non-

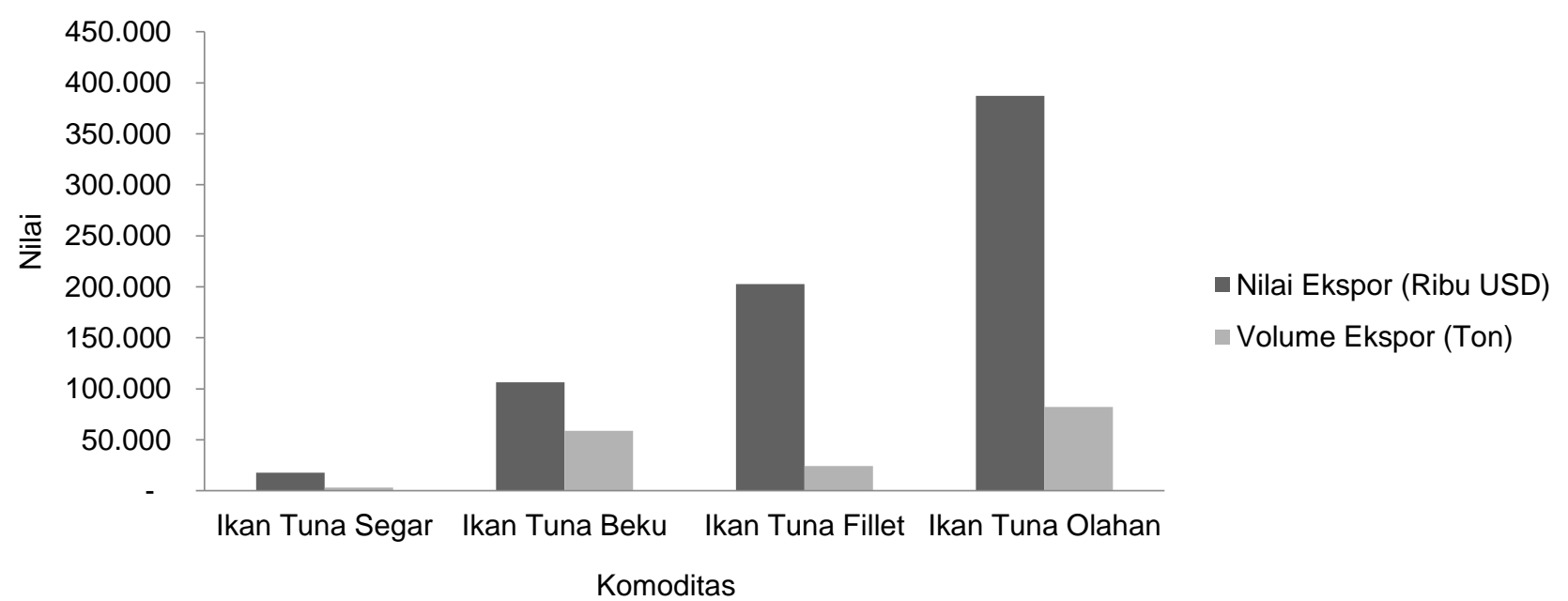

Gambar 1 Eskpor ikan tuna berdasarkan bentuk tahun 2018.

Sumber: Diolah dari International Trade Centre (ITC) Trademap 2019. 
tarif yang dipilih adalah kebijakan SPS dan TBT karena kebijakan tersebut merupakan yang terbanyak diterapkan pada produk pertanian. Pada variabel kebijakan non-tarif berupa SPS dan TBT digunakan jumlah tindakan yang diterapkan. Formulasi crosssectional gravity model pada penelitian ini dituliskan dengan persamaan berikut:

In $\operatorname{EXP}_{i j}=\beta_{0}+\beta_{1}$ In GDP $+\beta_{2}$ In $P O P_{j}+\beta_{3}$ In ECODISTt $_{i j}+\beta_{4}$ In ER $\mathrm{ER}_{\mathrm{ij}}+\beta_{5}$ In $\mathrm{PRC}_{\mathrm{ij}}+\beta_{6} \mathrm{TRF}_{\mathrm{ij}}+\beta_{7}$ $\mathrm{SPS}_{\mathrm{ij}}+\beta_{8} \mathrm{TBT}_{\mathrm{ij}}+\mathcal{E}_{\mathrm{ij}}$

Keterangan:

$\beta_{0}$

$\beta_{1,2,3,4, n=\text { Konstanta setiap variabel bebas }}$

EXP $_{\mathrm{ij}} \quad=$ Volume ekspor produk olahan ikan Indonesia ke negara $j$

$\mathrm{GDP}_{\mathrm{j}} \quad=$ GDP riil perkapita negara $\mathrm{j}$

$\mathrm{POP}_{\mathrm{j}} \quad=$ Populasi negara $j$

ECODIST $_{i j}=$ Jarak ekonomi dari Indonesia ke negara $j$

$\mathrm{ER}_{\mathrm{ij}} \quad=$ Nilai tukar rupiah terhadap mata uang negara $j$

$\mathrm{TRF}_{\mathrm{j}} \quad=$ Tarif impor tuna negara $j$

$\mathrm{PRC}_{\mathrm{ij}}=$ Harga ekspor ikan tuna Indonesia di negara $j$

$\mathrm{SPS}_{\mathrm{ij}} \quad=$ Jumlah item SPS yang diberlakukan negara pengimpor $j$ pada negara pengekspor $i$.

TBT $_{\mathrm{ij}} \quad=$ Jumlah item TBT yang diberlakukan negara pengimpor $j$ pada negara pengekspor $i$.

$i=$ Data cross section Indonesia

$j \quad=$ Data cross section negara tujuan

$\varepsilon_{\mathrm{ij}} \quad=$ Galat

\section{Uji Asumsi Klasik}

Asumsi klasik yang diuji meliputi uji normalitas, uji multikolinearitas, uji heteroskedastisitas, dan uji autokorelasi. Normalitas diuji guna mengidentifikasi error term apakah sudah terdistribusi secara normal atau tidak. Normalitas diuji dengan menggunakan analisis grafik melalui uji jarque bera. Jika nilai probabilitas jarque bera $>0,05$, model tersebut dapat dinyatakan menyebar normal.

Multikolinearitas diuji untuk menentukan apakah dalam model regresi terdapat korelasi antarvariabel bebas (Ghozali 2011). Multikolinearitas menyebabkan nilai $R^{2}$ menjadi tinggi, akan tetapi sedikit variabel yang

Tabel 1 Jenis dan sumber data penelitian nyata dan arah koefisien variabel menjadi tidak valid untuk ditafsir secara teori ekonomi. Multikolinearitas dapat dideteksi dengan menghitung variance inflation factor (VIF). Apabila nilai VIF $<10$, berarti tidak terdapat multikoneliaritas (Gujarati, 2004).

Heteroskedastisitas adalah salah satu penyimpangan pada asumsi klasik statistika. Heteroskedastisitas terjadi jika nilai residual dari model tidak memiliki varians yang konstan. Masalah ini sering terjadi tidak hanya pada penggunaan data cross section dalam estimasi model, tetapi juga dalam data deret waktu (Gujarati, 2004). Salah satu cara untuk mengatasi pelanggaran ini ialah dengan metode generalized least square (GLS) yang merupakan metode kuadrat terkecil yang terboboti, dengan model ditransformasikan melalui pembobotan pada data asli (Juanda, 2009).

Autokorelasi adalah korelasi yang tinggi antargalatnya $(\mu)$, yakni dengan cara membandingkan nilai Durbin-Watson (DW) hasil estimasi dengan nilai DW tabel. Jika nilai DW berada pada area nonautokorelasi mendekati 2, dapat disimpulkan bahwa model bebas dari masalah autokrelasi. Tabel 2 memperlihatkan distribusi nilai DW.

\section{Pengujian Parameter Model}

Pengujian parameter model bertujuan menetapkan kelayakan model dan apakah koefisien yang diestimasi telah sesuai dengan teori atau hipotesis. Pengujian parameter meliputi koefisien determinasi $\left(R^{2}\right)$, uji koefisien regresi secara menyeluruh ( $F$-test/uji F), dan uji koefisien regresi secara parsial (uji $t$ ).

Uji-F digunakan untuk menguji hipotesis koefisien (slope) regresi atau parameter model secara menyeluruh. Kriteria pengujiannya adalah jika nilai nilai $F_{\text {observasi }}>F_{\text {tabel }}$ atau nilai probabilitas $F$-statistik $<$ taraf nyata ( $\alpha$ ), maka keputusan menolak $\mathrm{HO}$ signifikan. Dengan menolak $\mathrm{HO}$, berarti sekurang-kurangnya ada satu peubah bebas yang berpengaruh nyata pada peubah takbebas.

Tabel 2 Selang nilai statistik Durbin-Watson serta keputusannya

\begin{tabular}{ll}
\hline \multicolumn{1}{c}{ Nilai Durbin-Watson } & \multicolumn{1}{c}{ Kesimpulan } \\
\hline $4-d l<D W<4$ & Ada autokorelasi \\
$4-d u<D W<4-d l$ & Tidak ada kesimpulan \\
$2<D W<4$-du & Tidak ada korelasi \\
du $<\mathrm{DW}<2$ & Tidak ada korelasi \\
$\mathrm{dl}<\mathrm{DW}<\mathrm{du}$ & Tidak ada kesimpulan \\
$0<\mathrm{DW}<\mathrm{dl}$ & Ada autokorelasi
\end{tabular}

Keterangan: DW = Durbin-Watson.

Sumber: Gujarati 2004.

\begin{tabular}{lll}
\hline \multicolumn{1}{c}{ Jenis data } & \multicolumn{1}{c}{ Sumber } & Satuan \\
\hline Nilai dan volume ekspor & ITC-Trademap, UN Comtrade & US\$ \\
GDP rill per kapita & Worldbank & US\$ \\
Populasi & Worldbank & Individu \\
Jarak geografis & CEPII & Km.US\$ \\
Nilai tukar riil & Worldbank & Rp/LCU \\
Tarif impor & Macmap & Persen \\
NTM (SPS dan TBT) & Macmap & Item \\
\hline
\end{tabular}

Keterangan: NTM = non-tariff measure, SPS = sanitary and phytosanitary measures, dan TBT = technical barriers to trade. 
Setelah koefisien regresi diuji secara keseluruhan langkah selanjutnya adalah menguji koefisien regresi secara parsial menggunakan uji-t. Hipotesis pada uji- $t$ adalah $\mathrm{HO}: \beta i=0$ vs $\mathrm{H} 1: \beta i \neq 0$. Keputusan dalam pengujian ini ditarik dengan membandingkan nilai $t$ hitung dengan $t$-tabel, atau dengan mempertimbangkan nilai probabilitas dari $t$-hitung. Jika nilai $t$ hitung $>t$-tabel, atau jika nilai probabilitas $t<\alpha=0,05$, maka keputusan menolak $\mathrm{HO}$ adalah nyata. Kesimpulannya adalah peubah bebas secara parsial nyata memengaruhi peubah takbebas.

Selanjutnya ialah uji koefisien determinasi $\left(R^{2}\right)$. Nilai uji $R^{2}$ mengukur kecocokan (goodnes of fit) persamaan regresi, yaitu memberi proporsi atau persentase variasi total dalam variabel takbebas yang dijelaskan oleh variabel bebas, atau merupakan ukuran yang menunjukkan seberapa baik garis regresi sampel menggambarkan populasi. Dengan kata lain, uji $R^{2}$ digunakan untuk menghitung seberapa besar variasi dari variabel bebas yang dapat menjelaskan variasi dari variabel takbebas. Nilainya berkisar antara 0 dan 1. Jika nilai $R^{2}$ sama dengan 1 , maka variasi variabel bebas mampu menjelaskan $100 \%$ variasi variabel takbebas. Sebaliknya jika nilai $R^{2}$ sama dengan 0 , maka variasi variabel bebas tidak mampu menjelaskan sedikitpun variasi variabel takbebas. Kecocokan model dikatakan "lebih baik" jika nilai $R^{2}$ semakin mendekati 1.

\section{HASIL DAN PEMBAHASAN}

\section{Kebijakan Tarif Negara-Negara Importir atas Tuna Olahan Indonesia}

Tarif impor adalah pungutan yang dikenakan pada barang ketika masuk ke batas negara. Tarif impor biasanya dihubungkan dengan proteksionisme, yakni kebijakan ekonomi yang membatasi perdagangan antarnegara. Telah banyak perundingan perdagangan internasional atau perjanjian multirateral untuk mengurangi hambatan tarif ini. Banyak tarif perdagangan yang dihapuskan, tetapi komoditas tertentu seperti produk perikanan masih membutuhkan proteksi lebih sehingga kebijakan tarif impor tetap diberlakukan pada komoditas tersebut. Besar tarif yang dikenakan pada produk impor di suatu negara bergantung pada negara asal produk tersebut.

Tabel 3 merupakan daftar besarnya kebijakan tarif negara importir tuna olahan yang dikenakan bagi Indonesia. Kebijakan tarif terbesar untuk komoditas tuna olahan Indonesia diterapkan oleh Amerika Serikat, yaitu $35 \%$, padahal negara ini merupakan salah satu tujuan utama ekspor tuna olahan Indonesia. Tarif terbesar kedua diterapkan oleh negara Algeria, yaitu $30 \%$. Negara-negara importir tuna olahan Indonesia yang termasuk ke dalam Uni Eropa juga menerapkan tarif yang cukup besar, sampai $20,5 \%$.

\section{Kebijakan Non-tarif Negara-Negara Importir atas Tuna Olahan Indonesia}

Kebijakan non-tarif yang diberlakukan oleh negaranegara importir atas tuna olahan asal Indonesia meliputi tindakan SPS, TBT, inspeksi pra-pengiriman, lisensi, kuota, dan tindakan kontrol kuantitas lainnya, tindakan pengendalian harga, tindakan keuangan, tindakan yang memengaruhi persaingan, dan hak milik intelektual.

\section{- Sanitary and Phytosanitary Measures (SPS)}

Kebijakan non-tarif yang terbanyak diterapkan atas tuna olahan Indonesia ialah tindakan SPS. Tindakan ini diterapkan untuk melindungi kehidupan manusia atau hewan dari risiko yang timbul dari zat aditif, kontaminan, racun, atau organisme penyebab penyakit dalam makanan. Hampir semua negara importir tuna olahan Indonesia menerapkan persyaratan tindakan SPS, kecuali Togo. China merupakan negara yang terbanyak menerapkan SPS dengan jumlah 57 tindakan. Terbanyak kedua ditempati oleh Amerika Serikat yang merupakan negara importir utama tuna olahan dunia dengan jumlah tindakan SPS mencapai 50. Algeria, Arab Saudi, Bahrain, dan UEA juga termasuk negara importir yang banyak menerapkan tindakan SPS atas tuna olahan Indonesia. Adapun negara importir yang tergabung dalam Uni Eropa menerapkan tindakan SPS yang sama, dengan jumlah 10 tindakan. Terdapat 35 jenis kebijakan SPS yang diberlakukan oleh negara importir atas tuna olahan Indonesia. Jenis kebijakan SPS yang terbanyak diberlakukan ialah persyaratan pelabelan, sertifikasi,

Tabel 3 Tarif negara pengimpor atas ikan tuna olahan Indonesia

\begin{tabular}{lrlrlrlr}
\hline \multicolumn{1}{c}{ Negara } & Tarif $(\%)$ & Negara & Tarif $(\%)$ & Negara & Tarif $(\%)$ & \multicolumn{1}{c}{ Negara } & Tarif $(\%)$ \\
\hline Algeria & 30,0 & Estonia & 20,5 & Lebanon & 0,0 & Romania & 20,5 \\
AS & 35,0 & Filipina & 0,0 & Lithuania & 20,5 & Selandia Baru & 0,0 \\
Arab Saudi & 5,0 & Hongkong & 0,0 & Malaysia & 0,0 & Singapura & 0,0 \\
Australia & 0,0 & Inggris & 20,5 & Meksiko & 20,0 & Slovenia & 20,5 \\
Bahrain & 5,0 & Italia & 20,5 & Nigeria & 20,0 & Spanyol & 20,5 \\
Belanda & 20.5 & Jepang & 20,5 & Oman & 5,0 & Togo & 20,0 \\
Belgia & 20,5 & Jerman & 20,5 & Perancis & 20,5 & UEA & 5,0 \\
Bulgaria & 20,5 & Kanada & 4,5 & Polandia & 20,5 & Viet Nam & 0,0 \\
Ceko & 20,5 & Kroasia & 20,5 & Portugal & 20,5 & Yordania & 0,0 \\
China & 0,0 & Kuwait & 5,0 & Qatar & 5,0 & Yunani & 20,5 \\
\hline
\end{tabular}

Sumber: Diolah dari International Trade Centre (ITC) Macmap 2019. 
kemasan, dan persyaratan batas toleransi residu (Tabel 4).

\section{- Technical Barriers to Trade (TBT)}

Kebijakan non-tarif terbanyak kedua setelah tindakan SPS adalah tindakan TBT. TBT merupakan tindakan yang mengacu pada peraturan teknis dan prosedur asesmen terkait kesesuaian dengan peraturan teknis yang tidak termasuk ke dalam cakupan tindakan SPS. Tindakan TBT atas tuna olahan Indonesia meliputi sertifikasi, pelabelan, pengemasan produksi, kualitas produksi atau persyaratan kinerja, trasportasi dan penyimpanan, serta penilaian kelayakan TBT. Seperti pada tindakan SPS, peraturan pelabelan dan sertifikasi merupakan persyaratan yang terbanyak diterapkan pada kebijakan TBT. Pelabelan pada TBT memuat informasi teknis pada produk seperti instruksi penggunaan. Beberapa jenis tindakan TBT yang terbanyak diterapkan oleh negara importir tuna olahan Indonesia dapat dilihat pada Tabel 5. Pemberlakuan tindakan TBT tertinggi pada komoditas ini adalah juga China, sebanyak 49 tindakan, sedangkan negara importir tuna olahan Indonesia lainnya masih di bawah 20 tindakan. Oman merupakan satu-satunya yang tidak menerapkan kebijakan nontarif berupa TBT pada tuna olahan asal Indonesia. Nigeria dan Yordania hanya melakukan satu jenis tindakan TBT untuk tuna olahan Indonesia. Nigeria hanya menerapkan persyaratan pelabelan, sedangkan Yordania hanya menerapkan persyaratan kualitas, keamanan, dan kinerja produk.

\section{- Inspeksi pra-pengiriman}

Penerapan tindakan inspeksi pra-pengiriman oleh negara-negara importir tuna olahan Indonesia cenderung lebih sedikit dibandingkan dengan tindakan SPS dan TBT. Dari 40 negara pengimpor hanya 27 negara yang menerapkan tindakan inspeksi prapengiriman. Bahrain merupakan negara pengimpor tuna olahan Indonesia yang menerapkan jumlah tindakan inspeksi pra-pengiriman terbanyakm yaitu enam tindakan. Ekspor menuju negara pengimpor yang tergabung dalam Uni Eropa memiliki satu tindakan inspeksi pra-pengiriman. Tindakan tersebut adalah tindakan pemantauan dan pengawasan kebutuhan impor serta perizinan otomatis lainnya yang mencakup kode NTM C400. Jenis tindakan inspeksi pra-pengiriman dengan kode NTM C400 juga merupakan tindakan yang terbanyak diterapkan oleh negara pengimpor tuna olahan Indonesia (Tabel 6). Arab Saudi, Bahrain, Filipina, Meksiko, dan UEA menerapkan tindakan inspeksi pra-pengiriman berupa persyaratan untuk melewati pelabuhan pabean yang ditentukan. Selain itu, Kanada menerapkan tindakan persyaratan pengiriman langsung, yaitu tuna olahan Indonesia yang diekspor ke Kanada harus dikirim langsung dari Indonesia tanpa negara perantara.

\section{- Lisensi, kuota, dan tindakan kontrol kuantitas lainnya}

Kebijakan non-tarif dalam klasifikasi ini merupakan tindakan pengendalian yang umumnya ditujukan untuk melarang atau membatasi impor. Tindakan ini dapat

Tabel 4 Jenis tindakan Sanitary and Phytosanitary Measures yang terbanyak diberlakukan atas tuna olahan Indonesia

\begin{tabular}{llc}
\hline Kode NTM & & $\begin{array}{c}\text { Jumlah negara } \\
\text { importir }\end{array}$ \\
\hline A310 & Persyaratan pelabelan & 35 \\
A840 & Persyaratan inspeksi & 33 \\
A210 & Batas toleransi untuk residu atau kontaminasi zat tertentu (non-mikrobiologis) & 33 \\
A830 & Persyaratan sertifikasi & 32 \\
A330 & Persyaratan pengemasan & 32 \\
A820 & Persyaratan pengujian & 29 \\
A410 & Kriteria mikrobiologis pada produk akhir & 28 \\
A120 & Larangan geografis pada eligibilitas & 19 \\
A400 & Persyaratan higienis terkait dengan SPS & 17 \\
A590 & Perlakuan untuk mengeliminasi hama tumbuhan dan hewan atau organisme & 16 \\
& penyebab penyakit dalam produk akhir n.e.s. atau larangan perlakuan & 16 \\
\hline
\end{tabular}

Keterangan: n.e.s = not elsewhere specified dan NTM = non-tariff measure.

Sumber: Diolah dari International Trade Centre (ITC) Macmap 2019.

Tabel 5 Jenis tindakan Technical Barriers to Trade yang terbanyak diberlakukan atas tuna olahan Indonesia

\begin{tabular}{llc}
\hline Kode NTM & Tindakan & Jumlah negara importir \\
\hline B830 & Persyaratan sertifikasi & 28 \\
B330 & Persyaratan pengemasan & 23 \\
B600 & Persyaratan identitas produk & 20 \\
B310 & Persyaratan pelabelan & 17 \\
B140 & Persyaratan otorisasi untuk alasan TBT & 8 \\
B700 & Persyaratan mutu produk, keamanan atau kinerja & 8 \\
B820 & Persyaratan pengujian & 6 \\
B840 & Persyaratan inspeksi & 4 \\
B420 & Peraturan TBT mengenai transpor dan penyimpanan & 4 \\
B890 & Asesmen kesesuaian terkait TBT, n.e.s. & 4 \\
\hline
\end{tabular}

Keterangan: n.e.s. $=$ not elsewhere specified dan NTM = non-tariff measure.

Sumber: Diolah dari International Trade Centre (ITC) Macmap 2019. 
berupa lisensi non-otomatis, penetapan kuota yang telah ditentukan, atau larangan. Sepuluh negara pengimpor tuna olahan Indonesia menerapkan tindakan non-tarif dalam cakupan ini, yakni Filipina, China, Algeria, Arab Saudi, Bahrain, Togo, Australia, Kuwait, Selandia Baru, dan Viet Nam. Filipina merupakan negara yang terbanyak jumlah tindakan non-tarif ini, yaitu sepuluh tindakan, disusul oleh China yang menerapkan tujuh tindakan. Negara lainnya hanya menerapkan kebijakan pada klasifikasi ini jumlahnya di bawah tiga tindakan. Terdapat sembilan jenis tindakan yang diterapkan oleh negara-negara importir. Persyaratan terkait prosedur perizinan impor non-otomatis selain otorisasi untuk alasan SPS atau TBT merupakan yang terbanyak diterapkan oleh tujuh negara, yaitu Filipina, China, Algeria, Togo, Australia, Selandia Baru, dan Viet Nam. Di Filipina, persyaratan mengenai lisensi ditambah dengan tindakan lisensi kode E113 yang merupakan lisensi terkait dengan produksi lokal (Tabel 7).

\section{- Tindakan pengendalian harga}

Kebijakan non-tarif lainnya yang sering diberlakukan pada tuna olahan Indonesia adalah tindakan pengendalian harga, yaitu untuk mengendalikan atau memengaruhi harga barang impor. Tindakan kontrol harga tersebut bertujuan antara lain untuk mendukung harga domestik dari produk tertentu ketika harga impor barang-barang tersebut lebih rendah, mendirikan harga domestik produk tertentu karena fluktuasi harga di pasar domestik, atau ketidakstabilan di pasar luar negeri, serta untuk meningkatkan atau mempertahankan pendapatan pajak. Kategori ini juga termasuk tindakan selain tindakan tarif yang dapat meningkatkan biaya impor dengan cara yang sama, yaitu dengan persentase tetap atau jumlah tetap yang dikenal juga sebagai para-tariff measures. Bahrain, China, Selandia Baru, dan Togo merupakan negara pengimpor tuna olahan Indonesia yang menerapkan tindakan pengendalian harga. Jenis tindakan yang diberlakukan oleh Bahrain berupa pajak internal dan biaya yang dikenakan atas impor. Adapun China, Selandia Baru, dan Togo menerapkan pajak konsumsi, yaitu pajak atas penjualan produk (Tabel 8).

\section{- Tindakan keuangan}

Tindakan keuangan dimaksudkan untuk mengatur akses dan biaya devisa atas impor dan menentukan persyaratan pembayaran. Tindakan keuangan dapat meningkatkan biaya impor dengan cara yang sama sebagai tindakan tarif. Kebijakan yang berkaitan dengan tindakan keuangan diterapkan oleh Filipina, Oman, Togo, dan Viet Nam. Filipina menerapkan tindakan keuangan berupa advance payment of customs duties. Persyaratan tersebut memuat pembayaran semua atau sebagian bea masuk di muka. Oman menerapkan tindakan bank authorization, yaitu persyaratan untuk mendapatkan otorisasi impor khusus dari bank sentral. Togo menerapkan dua jenis tindakan non-tarif yang berkaitan dengan keuangan. Pertama, advance import deposits, yaitu persyaratan yang berlaku bahwa importir harus menyetor persentase dari nilai transaksi impor sebelum menerima barang. Kedua, regulations concerning terms of payment for imports, yaitu peraturan yang berkaitan dengan kondisi pembayaran impor dan

Tabel 8 Jenis tindakan pengendalian harga yang diberlakukan atas tuna olahan Indonesia

\begin{tabular}{|c|c|c|}
\hline $\begin{array}{l}\text { Kode } \\
\text { NTM }\end{array}$ & Tindakan & $\begin{array}{c}\text { Jumlah negara } \\
\text { importir }\end{array}$ \\
\hline F700 & Pajak internal dan pajak impor & 1 \\
\hline F710 & Pajak konsumsi & 6 \\
\hline
\end{tabular}

Keterangan: NTM = non-tariff measure.

Sumber: Diolah dari International Trade Centre (ITC) Macmap 2019.

Tabel 6 Jenis tindakan inspeksi pra-pengiriman yang diberlakukan atas tuna olahan Indonesia

\begin{tabular}{|c|c|c|}
\hline Kode NTM & Tindakan & $\begin{array}{c}\text { Jumlah negara } \\
\text { importir }\end{array}$ \\
\hline C100 & Inspeksi pra-pengiriman & 1 \\
\hline C200 & Persyaratan consignment langsung & 1 \\
\hline C300 & Persyaratan melewati pelabuhan atau pabean tertentu & 5 \\
\hline C400 & Persyaratan pemantauan impor dan surveilans dan tindakan lisensi otomatis lain & 21 \\
\hline C900 & Formalitas lain, n.e.s.. & 5 \\
\hline
\end{tabular}

Keterangan: n.e.s. $=$ not elsewhere specified dan NTM = non-tariff measure.

Tabel 7 Jenis tindakan lisensi, kuota, dan kontrol kuantitas yang diberlakukan atas tuna olahan Indonesia

\begin{tabular}{llc}
\hline Kode NTM & \multicolumn{1}{c}{ Tindakan } & Jumlah negara importir \\
\hline E100 & Prosedur lisensi impor non-otomatis selain otorisasi karena alasan SPS atau TBT & 7 \\
E200 & Kuota & 2 \\
E321 & Larangan karena alasan agama, moral, atau budaya & 2 \\
E322 & Larangan karena alasan politis (embargo) & 2 \\
E113 & Lisensi yang dikaitkan dengan produksi lokal & 1 \\
E231 & Alokasi global & 1 \\
E313 & Larangan sementara, termasuk suspensi penerbitan lisensi & 1 \\
E320 & Larangan karena alasan non-ekonomi & 1 \\
\hline
\end{tabular}

Keterangan: NTM = non-tariff measure.

Sumber: Diolah dari International Trade Centre (ITC) Macmap 2019. 
perolehan serta penggunaan kredit asing atau domestik untuk membiayai impor. Viet Nam menerapkan tindakan keuangan lainnya yang tercakup dalam kode G900 (Tabel 9).

\section{- Tindakan yang memengaruhi persaingan}

Tindakan yang memengaruhi persaingan adalah tindakan yang memberikan preferensi atau hak khusus atau eksklusif kepada satu atau lebih grup operator ekonomi. Pada tuna olahan asal Indonesia tindakan klasifikasi ini diberlakukan oleh Filipina dan Viet Nam (Tabel 10).

\section{- Hak milik intelektual}

Tindakan dalam klasifikasi ini berisi langkahlangkah terkait hak kekayaan intelektual dalam perdagangan. Peraturan perundang-undangan hak milik intelektual mencakup paten, merek dagang, desain industri, desain tata letak sirkuit terpadu,hak cipta, indikasi geografis dan rahasia dagang. Hak yang diberikan terdaftar di Kantor Nasional dan dikumpulkan dalam database World Intellectual Property Organization (WIPO). China merupakan satu-satunya negara importir tuna olahan Indonesia yang menerapkan kebijakan non-tarif berupa hak milik intelektual (Tabel 11).

\section{Uji Kelayakan dan Kecocokan Model (Goodness of fit)}

Kelayakan dan kecocokan model (goodness of fit) diuji guna mendapatkan model yang terbaik. Uji kelayakan model menunjukkan nilai probabilitas ( $F$ statistik) sebesar 0,000 . Nilai tersebut lebih kecil daripada taraf nyata $5 \%$ sehingga secara keseluruhan model layak digunakan, dan setidaknya ada satu variabel bebas yang memengaruhi variabel takbebas. Uji kecocokan model menunjukkan nilai koefisien determinasi $\left(R^{2}\right)$. Semakin besar nilai koefisien determinasi, semakin besar pengaruh variabel bebas pada variabel takbebas. Nilai $R^{2}$ pada model sebesar 0,71 berarti variasi variabel bebas berupa GDP riil per kapita, populasi, jarak ekonomi, nilai tukar riil, harga ekspor, kebijakan tarif dan kebijakan non-tarif mampu menjelaskan variabel takbebas (volume ekspor) sebesar $71 \%$, sedangkan sisanya dijelaskan oleh faktor-faktor lainnya di luar model.

\section{Uji Asumsi Dasar}

Asumsi dasar diuji untuk memperoleh estimasi yang bersifat BLUE (best linear unbiased estimator). Asumsi dasar yang diuji meliputi uji normalitas, uji multikolinearitas, uji heteroskedastisitas, dan uji autokorelasi. Uji normalitas digunakan untuk mengevaluasi bahwa data telah berdistribusi normal atau tidak. Nomalitas diuji dengan menggunakan uji Jarque-Bera. Uji ini mempunyai nilai chi-square dengan derajat bebas dua. Nilai Jarque-Bera adalah 0,61 dengan nilai probabilitas 0,74 . Oleh karena itu dapat disimpulkan bahwa data pada model kedua juga berdistribusi normal dengan nilai probabilitas lebih besar daripada 0,05 .

Multikolinearitas yang diuji pada model mengindikasikan bahwa tidak terdapat pelanggaran multikolinearitas pada model. Sebagaimana ditunjukkan pada Tabel 12, nilai centered VIF setiap variabel indipenden tidak lebih besar daripada 10. Ada atau tidaknya masalah autokorelasi pada model dapat dilihat dari nilai Durbin Watson. Dengan sampel $(n) 40$ dan jumlah variabel bebas 8 , maka nilai dL adalah 1,06 dan nilai dU adalah 1,99. Dengan demikian, nilai 4-dL adalah 2,94 dan nilai 4-dU adalah 2,01. Nilai dW yang diperoleh dari estimasi model adalah 2,00. Berhubung nilai dW masih berada di antara nilai dU $(1,99)$ dan 4dU $(2,01)$, disimpulkan bahwa tidak terdapat masalah autokorelasi pada model.

Proses pengujian heteroskedastisitas dalam penelitian ini adalah dengan menggunakan uji Glesjer, yang meregresikan variabel-variabel bebas terhadap residual absolut. Nilai probabilitas chi square yang dihasilkan pada model adalah 0,23 . Oleh karena nilai tersebut lebih tinggi daripada 0,05, dapat disimpulkan tidak terdapat pelanggaran heteroskedastisitas pada model.

Tabel 10Jenis tindakan yang memengaruhi persaingan yang diberlakukan terhadap tuna olahan Indonesia

\begin{tabular}{ccc}
\hline Kode & Tindakan & $\begin{array}{c}\text { Jumlah negara } \\
\text { importir }\end{array}$ \\
\hline H000 & $\begin{array}{c}\text { Tindakan yang memengaruhi } \\
\text { persaingan }\end{array}$ & 1 \\
H900 & $\begin{array}{c}\text { Tindakan yang memengaruhi } \\
\text { persaingan, n.e.s. }\end{array}$ & 1
\end{tabular}

Keterangan: n.e.s. $=$ not elsewhere specified dan NTM = non-tariff measure.

Tabel 11Jenis tindakan hak milik intelektual yang diberlakukan atas tuna olahan Indonesia

\begin{tabular}{ccc}
\hline $\begin{array}{c}\text { Kode } \\
\text { NTM }\end{array}$ & Tindakan & $\begin{array}{c}\text { Jumlah negara } \\
\text { importir }\end{array}$ \\
\hline N000 & Hak milik intelektual & 1 \\
\hline
\end{tabular}

Keterangan: NTM = non-tariff measure.

Tabel 9 Jenis tindakan keuangan yang diberlakukan atas tuna olahan Indonesia

\begin{tabular}{|c|c|c|}
\hline Kode NTM & Tindakan & $\begin{array}{c}\text { Jumlah negara } \\
\text { importir }\end{array}$ \\
\hline G110 & n.e.s. $=$ not elsewhere specified & 1 \\
\hline G130 & n.e.s. $=$ not elsewhere specified & 1 \\
\hline G320 & n.e.s. $=$ not elsewhere specified & 1 \\
\hline G400 & n.e.s. $=$ not elsewhere specified & 1 \\
\hline G900 & n.e.s. $=$ not elsewhere specified & 1 \\
\hline
\end{tabular}

Keterangan: NTM = non-tariff measure

Sumber: Diolah dari International Trade Centre (ITC) Macmap 2019. 
Tabel 12 Hasil uji multikolineritas model tuna olahan

\begin{tabular}{|c|c|c|c|}
\hline \multirow[b]{2}{*}{ Variabel } & Koefisien & Uncentered & Centered \\
\hline & variance & VIF & VIF \\
\hline C & 5,874318 & 188,2387 & NA \\
\hline GDPJ & 0,016334 & 66,65152 & 1,568921 \\
\hline POPJ & 0,026493 & 240,8132 & 2,033612 \\
\hline ECODISTIJ & 0,018126 & 9,490347 & 1,692184 \\
\hline ERIJ & 0,015219 & 35,66176 & 1,679535 \\
\hline PRCIJ & 0,296306 & 18.35968 & 1,433758 \\
\hline TRFIJ & 0,028018 & 5,757903 & 1,346103 \\
\hline SPSIJ & 0,085060 & 24,11112 & 1,656403 \\
\hline TBTIJ & 0,090618 & 10,17019 & 1,234043 \\
\hline
\end{tabular}

Tabel 13 Hasil estimasi model gravitas tuna olahan

\begin{tabular}{|c|c|c|}
\hline \multirow{2}{*}{ Variabel bebas } & \multicolumn{2}{|c|}{ Model 2 (olahan) } \\
\hline & Koef. & Prob. \\
\hline GDP Negara Importir (GDPJ) & $0,319953^{* *}$ & 0,0178 \\
\hline Populasi (POPJ) & $0,455138^{* * *}$ & 0,0088 \\
\hline Jarak Ekonomi (ECODISTIJ) & $-0,231254^{*}$ & 0,0958 \\
\hline Nilai Tukar (ERIJ) & $0,274613^{* *}$ & 0,0334 \\
\hline Harga (PRCIJ) & $1,855924^{\star \star *}$ & 0,0018 \\
\hline Tariff (TRFIJ) & $-0,023479$ & 0,8894 \\
\hline Jumlah SPS (SPSIJ) & $0,705195^{\star *}$ & 0,0217 \\
\hline Jumlah TBT (TBTIJ) & $-0,972414^{\star * *}$ & 0,0029 \\
\hline R-Squared & 0,714310 & \\
\hline Adjusted R-Squared & 0,640584 & \\
\hline F-Statistic & 9,688659 & \\
\hline Prob (F-Statistic) & 0,000001 & \\
\hline
\end{tabular}

Keterangan: $\left.{ }^{\star \star *}\right)$ signifikan $\alpha=1 \%,{ }^{* *}$ signifikan $\alpha=5 \%,{ }^{*}$ signifikan $\alpha=10 \%$.

\section{Hasil Estimasi Model CrossSectional Gravity}

Hasil estimasi (Tabel 13) menunjukkan bahwa variabel GDP per kapita negara pengimpor berpengaruh positif dan nyata taraf nyata $5 \%$ pada volume ekspor tuna olahan Indonesia. Variabel GDP per kapita negara pengimpor memiliki koefisien 0,319. Hal ini berarti semakin tinggi nilai GDP per kapita suatu negara importir sebesar 1\% maka volume ekspor tuna olahan Indonesia semakin besar 0,319\% (ceteris paribus). GDP per kapita menggambarkan kemakmuran masyarakat di suatu negara dan dapat mengindikasikan seberapa besar ukuran daya beli masyarakat tersebut. Dengan begitu, semakin tinggi daya beli masyarakat di negara mitra dagang Indonesia maka volume komoditas yang dapat diekspor Indonesia seyogianya meningkat. Hasil tersebut didukung oleh penelitian Nguyen \& Wilson (2009); Dou et al. (2015); Khaliqi (2017) bahwa peningkatan GDP per kapita negara pengimpor akan menyebabkan terjadinya peningkatan impor.

Nilai koefisien variabel populasi negara pengimpor tuna olahan adalah 0,46 . Hal ini mengindikasikan jika populasi negara pengimpor semakin besar $1 \%$, maka volume ekspor tuna olahan Indonesia akan semakin besar $0,45 \%$ (ceteris paribus). Populasi yang tinggi pada negara pengimpor berbanding lurus dengan tingginya tingkat konsumsi suatu produk pada suatu negara. Konsumsi yang tinggi di negara pengimpor akan meningkatkan jumlah tuna olahan yang dapat diimpor. Dengan demikian, Indonesia sebagai negara pengeskpor dapat meningkatkan jumlah ekspornya di negara pengimpor tersebut. Penelitian Zarzoso dan
Lehmann (2003) mendukung pernyataan bahwa koefisien positif pada variabel populasi negara pengimpor menunjukkan ukuran suatu negara berhubungan langsung dengan perdagangan. Dengan kata lain, bigger countries memiliki kapasitas yang lebih besar untuk menyerap impor daripada smaller countries.

Jarak ekonomi merupakan salah satu syarat yang cukup penting pada gravity model. Jarak ekonomi mengindikasikan biaya ekspor (biaya transportasi) yang harus dikeluarkan pada saat terjadi perdagangan. Berdasarkan teori gravitas, jarak berpengaruh negatif pada hubungan perdagangan antarwilayah. Selaras dengan teori, model ini menghasilkan nilai koefisien yang bertanda negatif. Nilai koefisien dengan tanda negatif berarti apabila jarak dengan negara tujuan ekspor lebih jauh $1 \%$, maka ekspor tuna olahan Indonesia semakin kecil sebesar 0,23\% (ceteris paribus). Variabel jarak ekonomi ini berpengaruh nyata pada taraf nyata $10 \%$. Semakin jauh jarak negara pengimpor dengan Indonesia, semakin besar biaya transportasi untuk perdagangan tuna olahan dari Indonesia. Hal tersebut dapat menyebabkan semakin berkurangnya jumlah ekspor Indonesia ke negara pengimpor. Hasil ini didukung oleh penelitian Eita (2008) serta penelitian Bellanawithana dan Wijerathne (2009).

Ekspor suatu komoditas berkaitan dengan nilai tukar mata uang domestik terhadap mata uang negara lain. Bila nilai tukar riil meningkat atau mata uang negara pengekspor terdepresiasi, maka harga produk di negara pengekspor akan menjadi lebih murah 
sehingga mendorong permintaan produk dari negara pengimpor. Nilai tukar rupiah terhadap mata uang negara pengimpor tuna olahan yang diteliti berpengaruh nyata pada taraf $5 \%$ pada ekspor tuna olahan. Nilai yang diperoleh pada model ini menunjukkan koefisien positif 0,28 . Ini berarti bahwa semakin tinggi nilai tukar riil Indonesia dengan negara pengimpor sebesar 1\%, maka volume ekspor komoditas tuna olahan Indonesia semakin besar $0,28 \%$ (ceteris paribus). Temuan ini sejalan dengan penelitian Rahmah (2016) serta Zhiejie dan Jim (2018), bahwa depresiasi mata uang di negara pengekspor dapat menaikkan ekspor.

Harga merupakan salah satu faktor yang memengaruhi jumlah permintaan oleh konsumen; semakin tinggi harga yang ditetapkan, semakin menurun jumlah permintaan. Namun, jika dilihat dari sisi penawaran, peningkatan harga akan direspons dengan peningkatan penawaran. Harga komoditas dan penawaran mempunyai hubungan positif, maksudnya semakin tinggi harga di pasar, semakin terangsang produsen untuk menawarkan komoditasnya lebih banyak, demikian pula sebaliknya. Dalam penelitian ini, Indonesia adalah sebagai negara eksportir. Variabel harga ekspor pada model menghasilkan tanda koefisien positif. Hal ini dapat terlihat dari estimasi model kedua yang menghasilkan nilai dengan koefisien positif 1,86 dan nyata secara statistik pada taraf nyata $1 \%$. Jadi, jika harga ekspor $1 \%$ semakin tinggi, maka volume ekspor tuna olahan Indonesia semakin besar $1,86 \%$ (ceteris paribus). Temuan ini mendukung hasil penelitian Sitompul (2018), bahwa harga ekspor berpengaruh positif dan nyata pada nilai ekspor perikanan.

\section{Dampak Kebijakan Tarif dan Non-tarif atas Kinerja Ekspor Tuna Olahan Indonesia}

Tarif merupakan bentuk kebijakan perdagangan yang paling tua dan hambatan perdagangan paling transparan, yang secara tradisional digunakan sebagai sumber penerimaan pemerintah (Krugman dan Obstfeld, 2000). Ditinjau dari segi asal komoditas, ada dua macam tarif, yakni tarif impor dan tarif ekspor. Penelitian ini difokuskan pada dampak penerapan tarif impor. Tarif impor adalah pajak yang dibebankan pada komoditas yang diimpor dari negara lain. Beberapa penelitian sebelumnya oleh Fridhowati (2013), Wood et.al (2019), dan Sandaruwan et.al (2020) menunjukkan bahwa kebijakan tarif memengaruhi ekspor secara negatif yang artinya semakin tinggi tarif yang diterapkan negara pengimpor, maka ekspor semakin menurun. Sejalan dengan ini, variabel tarif impor menghasilkan koefisien yang bertanda negatif dengan nilai 0,14 . Hal tersebut berarti semakin tinggi tarif yang diberlakukan suatu negara importir sebesar satu-satuan maka volume tuna olahan yang dapat diekspor Indonesia semakin kecil sebesar 0,14 satuan (ceteris paribus). Namun, pengaruh tersebut tidak nyata.
Dampak pemberlakuan kebijakan non-tarif pada kinerja perdagangan dapat memiliki dua makna, yaitu positif dan negatif. Pada sisi negatif, kebijakan non-tarif ini dapat menyebabkan permintaan produk di pasar importir menjadi lebih rendah karena tingginya standar produk dan adanya kenaikan biaya perdagangan dari pihak eksportir sebagai hasil dari tindakan kebijakan tersebut. Sebaliknya, sisi positif ialah penetapan standar mutu yang harus dipenuhi oleh pihak eksportir dapat mengurangi asimetri informasi di antara negara (Bratt 2014). Seperti pada hasil estimasi model, tanda koefisien yang berbeda pada variabel kebijakan nontarif berupa SPS dan TBT.

Variabel kebijakan tarif berupa SPS menunjukkan koefisien yang positif dan berpengaruh nyata pada taraf nyata $5 \%$. Nilai koefisien tersebut adalah 0,71 , yang berarti jika semakin banyak tindakan SPS yang diterapkan suatu negara importir sebesar satu-satuan maka volume tuna olahan yang dapat diekspor Indonesia semakin besar 0,71 satuan (ceteris paribus). Koefisien positif pada variabel tersebut memperlihatkan bahwa pelaku usaha tuna olahan Indonesia telah mampu mengantisipasi penerapan kebijakan SPS dengan memenuhi standar dan aturan yang diberlakukan oleh negara pengimpor. Juga dapat membuktikan bahwa ternyata kebijakan SPS tidak selalu berdampak negatif pada perdagangan. Pengaruh positif kebijakan SPS pada arus perdagangan ekspor sejalan dengan studi Chen et al. (2008) yang melaporkan bahwa standar kualitas dan pelabelan berdampak positif pada volume dan cakupan ekspor. Dampak positif tersebut disebabkan oleh peningkatan standar mutu yang telah mengurangi ketidakpastian serta dapat meningkatkan willingness to pay konsumen. Selain itu, standar juga memastikan kompabilitas sebuah produk dan mengurangi kegagalan koordinasi antarprodusen. Pangsa pasar yang meningkat ini kemudian akan berdampak pada peningkatan volume perdagangan bagi para eksportir yang berhasil mengatasi biaya tetap ketika memasuki pasar. Rindayati dan Kristiana (2018) serta Fasarella et al. (2011) juga selaras dengan hasil penelitian ini.

Berbeda dengan hasil estimasi dampak kebijakan SPS, penerapan kebijakan TBT pada tuna olahan menghasilkan koefisien bertanda negatif, yaitu 0,97. Hasil estimasi tersebut menunjuklan bahwa semakin tinggi kebijakan TBT suatu negara importir sebesar satu-satuan, maka akan volume ekspor komoditas tuna olahan Indonesia semakin kecil sebesar 0,97 satuan (ceteris paribus). Hasil model yang menunjukkan dampak negatif TBT membuktikan bahwa Indonesia belum mampu memenuhi standar dan aturan yang diberlakukan oleh negara-negara pengimpor tuna olahan. Kebijakan TBT yang diterapkan negara pengimpor seperti sertifikasi, pelabelan, pengemasan produksi, kualitas produksi atau persyaratan kinerja, trasportasi dan penyimpanan, serta penilaian kelayakan TBT tentu saja dapat menghambat perdagangan tuna olahan. Hasil yang 
sama juga dilaporkan oleh Webb et al. (2017), Ardiyanti dan Saputri (2018), dan Wood et.al (2019).

\section{KESIMPULAN}

Penerapan kebijakan tarif tuna olahan Indonesia pada beberapa negara pengimpor masih cukup tinggi; Amerika Serikat dan Uni Eropa masing-masing menerapkan $35 \%$ dan $20,5 \%$, padahal kedua negara tersebut merupakan tujuan utama ekspor Indonesia. Kebijakan non-tarif berupa SPS dan TBT merupakan yang terbanyak diterapkan negara-negara importir pada tuna olahan asal Indonesia. Hasil estimasi model menunjukkan bahwa populasi negara pengimpor dan harga ekspor tuna olahan Indonesia berpengaruh positif dan nyata pada taraf nyata $1 \%$. GPD per kapita negara importir, nilai tukar, dan kebijakan SPS juga berpengaruh positif pada volume perdagangan tuna olahan Indonesia pada taraf nyata 5\%. Dengan demikian, semakin besar nilai variabel-variabel tersebut, semakin banyak produk tuna olahan Indonesia yang diekspor ke negara importir tersebut. Adapun, jarak ekonomi dan kebijakan TBT berpengaruh negatif dan nyata masing-masing pada taraf nyata $10 \%$ dan $1 \%$ pada besarnya volume ekspor. Semakin jauh jarak negara importir dan semakin banyak jumlah tindakan TBT yang diterapkan negara importir, semakin kecil volume ekspor. Selain itu, penerapan kebijakan tarif juga berpengaruh negatif pada besarnya volume ekspor ikan tuna olahan Indonesia meskipun tidak signifikan.

\section{DAFTAR PUSTAKA}

Bellanawithana A, Wijerathne B, Weerahewa J. 2009. Impacts of Non-Tariff Measures (NTMs) on Agricultural Exports: A Gravity Modeling Approach. Asia-Pacific Trade Economists Conference. University of Peradeniya, Srilanka: ESCAP

Dou L, Yanagishima K, Li X, Li P, Nakagawa M. 2015. Food safety regulation and its implication on Chinese vegetable exports. Food Policy. 57: 128-134. $\quad$ https://doi.org/10.1016/j.foodpol. 2015.09.007

Eita JH. 2008. Determinants of Namibian Exports: A Gravity Model Approach. The Journal of Developing Areas. 50(4): 1-12

[FAO] Food Agricultural Organization. 2019. FAO yearbook. Fishery and Aquaculture Statistics 2017 [Internet]. [diunduh 2019 Oktober 7]. Tersedia pada: http://www.fao.org/

Fassarella LM, de Souza MJP, Burnquist HL. 2011. Impact of Sanitary and Technical Measures on Brazilian Exports of Poultry Meat. Selected Paper prepared for presentation at the Agricultural \& Applied Economics Association's 2011 AAEA \&
NAREA Joint Annual Meeting July 24-26, 2011. Pittsburgh, Pennsylvania.

Fridhowati N. 2013. Dampak Non-tariff Measures (NTM) ASEAN terhadap Arus Perdagangan Sektor Elektronika Indonesia [tesis]. Bogor (ID): Institut Pertanian Bogor

Ghozali I. 2011. Application of multivariate analysis with SPSS program. Semarang (ID): Diponegoro University Publishing Agency.

Gujarati DN. 2004. Basic econometrics. New York (US): McGraw Hill Companies, Inc. Fourth Edition.

[ITC] International Trade Centre. 2019. Trade Map. List of Exporters for The Selected Product Internet]. [diunduh 2019 Desember 11]. https://trademap.org/

[ITC] International Trade Center. 2019. Market Acces Map. Market Acces Conditions [Internet]. [diunduh 2019 Desember 28]. https://www.macmap.org/

Irawati H, Kusnandar F, Kusumaningrum HD. 2019. Analisis penyebab penolakan produk perikanan indonesia oleh Uni eropa periode 2007-2017 dengan pendekatan Root cause analysis. Jurnal Standarisasi. 21(2): 149-160. https://doi.org/ 10.31153/js.v21i2.757

Juanda B. 2009. Ekonometrika Pemodelan dan Pendugaan. Bogor (ID): IPB Press.

[Kemendag] Kementerian Perdagangan Republik Indonesia (ID). 2011. Kajian kebijakan pengembangan diversifikasi pasar dan produk ekspor. Jakarta (ID): Badan Pengkajian Dan Pengembangan Kebijakan Perdagangan

[KKP] Kementrian Kelautan dan Perikanan. 2018. Pusat Data Statistik dan Informasi Kementerian Kelautan dan Perikanan. Kelautan dan Perikanan Dalam Angka Tahun 2018 [Internet]. [diunduh 2019 Oktober 10]. Tersedia pada http://sidatik.kkp.go.id/

Khaliqi M. 2017. Dampak Kebijakan Non-tariff Measures Terhadap Ekspor Udang Indonesia [tesis]. Bogor (ID): Institut Pertanian Bogor

Nguyen AVT, Wilson NLW. 2009. Effects of Food Safety Standars on Seafood Export to US, UE, and Japan (JP). In : Selected Paper Prepared for Presentational. The Southern Agricultural Economics Association Annual Meeting, Atlanta, Georgia, January 31 $1^{\text {th }}$-February $3^{\text {rd }}, 2009$.

Rahmah KN. 2016. Analisis Aliran Perdagangan Dan Peran Standar Dalam Perdagangan Tuna Kaleng [tesis]. Bogor (ID): Institut Pertanian Bogor.

Rindayati W, Kristriana OW. 2018. Impact analysis of Non-Tariff Measures (NTM) on Indonesian tuna exports to major destination countries. Jurnal Manajemen \& Agribisnis. 15(2): 172-185. https:// doi.org/10.17358/jma.15.2.172 
Sandaruwan K, Weerasooriya SA, Weerahewa J. 2020. Effects of Non-Tariff Measures on Seafood Exports from Sri Lanka: A Gravity Approach. Tropical Agricultural Research. 31(3): 11-24. https://doi.org/10.4038/tar.v31i3.8393

Sitompul TK. 2018. Pengaruh Fasilitasi Perdagangan terhadap Ekspor Perikanan Indonesia [tesis]. Bogor (ID): Institut Pertanian Bogor

[TRAINS] The Global Database on Non-Tariff Measures. 2019. Table by Measure [Internet]. [diunduh 2019 Oktober 10]. https://trains. unctad.org/

[UNCOMTRADE] UN Comtrade. 2019. UN Comtrade Database [Internet]. [diunduh 2019 Desember 30]. https://trains.unctad.org/

[UNCTAD] United Nations Conference on Trade and Development. 2010. Non-Tariff Measures: Evidence from Selected Developing Countries and Future Research Agenda. Developing Countries in International Trade Studies. New York and Geneva.
Webb M, Gibson J, Strutt A. 2017. Market access implications of non-tariff measures: Estimates for four developed country markets. The World Economy. 2018: 1-20. https://doi.org/10.1111/ twec. 12706

Wood J, Jie W, Li Y, Kim J. 2019. The impact of TBT and SPS measures on Japanese and Korean Exports to China. MDPI Sustainability. 11(6141). https://doi.org/10.3390/su11216141

Zarzoso IM, Lehmann FN. 2003. Augmented Gravity Model: An Empirical Application to MercosurEuropean Union Trade Flows. Journal of Applied Economics. 6(2): 291-316. https://doi.org/ 10.1080/15140326.2003.12040596

Zhijie G, Jim KFIPS. 2018. Determinants of bilateral trade between China and Africa: a gravity model approach. Journal of Economic Studies. 47(5): 1015-1038 